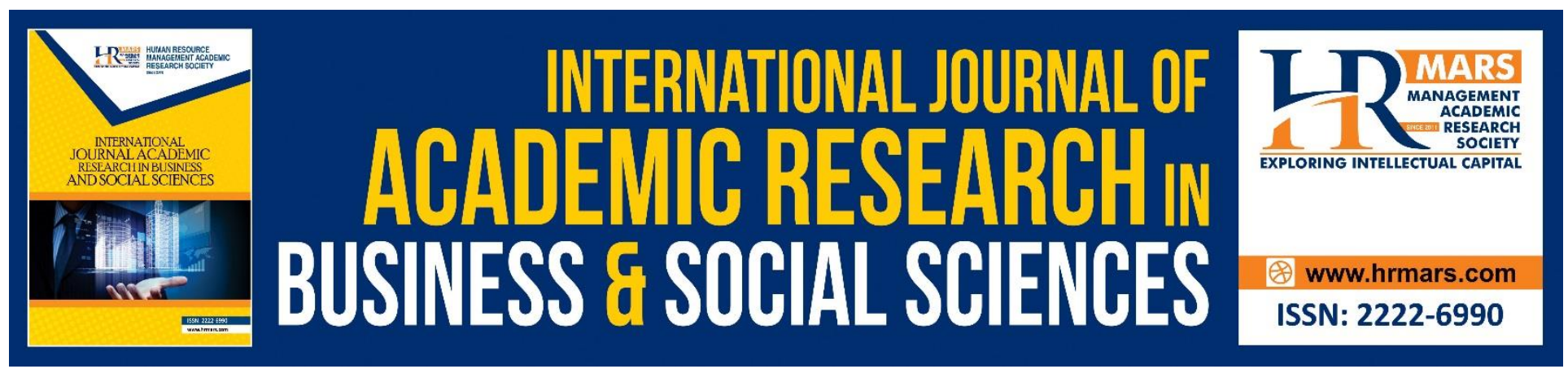

\title{
The Reality of UPSI Football Team Mentoring Program: A Qualitative Study
}

Zulakbal Abd Karim, Rozaireen Muszali, Hazuan Hizan, Yusri Yakub, Yusop
Ahmad, Sadzali Hassan \& Mohd Adib Adam Bin Mohd Suhaimi

To Link this Article: http://dx.doi.org/10.6007/IJARBSS/v9-i2/5546

DOI: $\quad 10.6007 /$ IJARBSS/v9-i2/5546

Received: 07 Jan 2019, Revised: 26 Feb 2019, Accepted: 10 March 2019

Published Online: 13 March 2019

In-Text Citation: (Karim et al., 2019)

To Cite this Article: Karim, Z. A., Muszali, R., Hizan, H., Yakub, Y., Ahmad, Y., Hassan, S., \& Suhaimi, M. A. A. B. M. (2019). The Reality of UPSI Football Team Mentoring Program: A Qualitative Study. International Journal of Academic Research in Business and Socal Sciences, 9(2), 312-321.

Copyright: @ 2019 The Author(s)

Published by Human Resource Management Academic Research Society (www.hrmars.com)

This article is published under the Creative Commons Attribution (CC BY 4.0) license. Anyone may reproduce, distribute, translate and create derivative works of this article (for both commercial and non-commercial purposes), subject to full attribution to the original publication and authors. The full terms of this license may be seen

at: http://creativecommons.org/licences/by/4.0/legalcode

\section{Vol. 9, No. 2, 2019, Pg. 312 - 321}

Full Terms \& Conditions of access and use can be found at http://hrmars.com/index.php/pages/detail/publication-ethics 


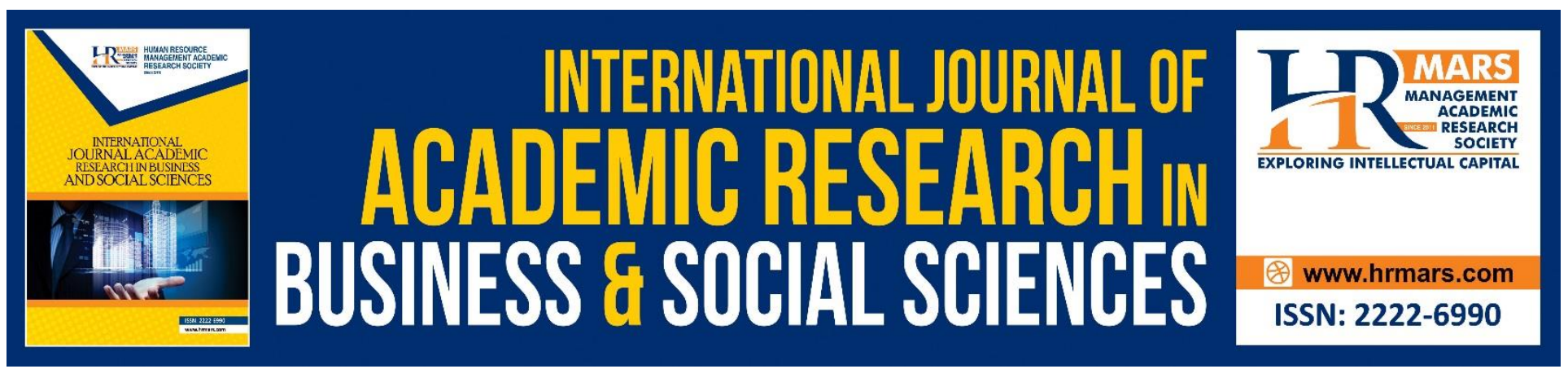

\title{
The Reality of UPSI Football Team Mentoring Program: A Qualitative Study
}

\section{Zulakbal Abd Karim, Rozaireen Muszali, Hazuan Hizan, Yusri Yakub, Yusop Ahmad, Sadzali Hassan \& Mohd Adib Adam Bin Mohd Suhaimi}

Faculty of Sports Science and Coaching, Universiti Pendidikan Sultan Idris, 35900 Tanjong Malim, Perak, Malaysia

Corresponding Author: zulakbal@fsskj.upsi.edu.my

\begin{abstract}
This study is conducted to identify how the mentoring program is used in sports and how this mentoring program takes place in a sports organization. The population of this study was UPSI students representing the university football team. The selected sample consists of approximately 25 people. The sample consists of players representing the university from the beginning of the student's entry or who have recently been involved in representing the university, but still have background in playing high-level football. The instrument of this study is observation. Observation method is a research method used to measure the research variables. Observation is also an alternative in collecting data other than questionnaires and interviews. Using this method, researchers should observe their samples within a certain timeframe. Prior to observation, researchers need to make good and careful planning. Each observation must have specific purpose, systematically done, focused, and must be recorded neatly and correctly. Notes made must be accurate, valid, and reliable. The findings showed that this mentoring program has a positive impact in the field of sports because mentoring can provide mentee with the necessary skills, self-esteem and self-esteem. Overall, through interactions with experienced mentors, a mentee can acquire skills such as mentor, team building, communication, problem solving, which can increase job satisfaction and increase productivity.
\end{abstract}

Keywords: Mentoring Program, Sport Organization, Mentor and Mentee

\section{Introduction}

An early study of the organization's mentoring system largely attributes the internal features of the mentoring program, which is the origin of concepts, goals, interests, practices and mentoring models inherent in society and organization (Hawkey, 1997; Irving, Moore \& Hamilton, 2003). This mentor is often someone who is experienced in the field that is being injected, while the mentee is defined as 
an individual with less knowledge and experience such as a student or athlete. Currently, this mentoring definition has been strengthened when current scholars make new interpretations of a general nature, integrated with various training methods, and adapted to various types of organizations operating in dynamic environments (Oliver \& Aggleton, 2002).

Mentors are defined as counselors, counselors, tutors, coaches or sponsors (Hunt \& Michael, 1983) while mentees are also known as protégés, who lack knowledge and experience or students who need guidance (Wright \& Werther Jr, 1991). Existing mentoring models are diverse and there is no single mentoring model that can be considered best and must be followed by all types of organizations. Most mentoring models are designed and administered according to the diversity and uniqueness of an organization in terms of trust, orientation, concern, pressure, strengths and weaknesses (Hawkey, 1997; Irving et al., 2003). Organizational differences have influenced the relationship between mentor and mente whether formal or informal (MacGregor, 2000).

The formal mentoring system emphasizes structured communication programs and processes, based on set measurements, has continuous action plans to achieve desired outcomes, determining start and end periods and specific objectives to be achieved, as well as identifying target areas which you want to focus on (Bahniuk \& Hill, 1998). Informal mentoring systems emphasize communication programs and processes based on special, ordinary, and spontaneous requirements. This mentoring program can act as a complement to formal mentoring programs (Goldstein \& Ford, 2002). If these two types of mentoring are practiced in a complementary manner, they will be able to form positive behavioral and behavioral behaviors. Furthermore, these attitudes and behaviors can help achieve organizational goals and strategies (Friday \& Friday, 2002).

A deeper study of the mentoring system found that the practices of the mentoring program were able to influence the advancement of mentees, especially students of higher learning institutions (Stewart \& Knowles, 2003). Specifically, communication between mentor and mentees and mentoring in mentoring programs are two very important forms of practice in the mentoring program. Implementation of this practice is designed to empower mentees to master new knowledge, skills and abilities to improve psychosocial and academic performance (Oliver \& Aggleton, 2002). Although the nature of this relationship is widely studied, the impact of the mentoring program on student or athlete development is less emphasized in the model of the mentoring system. Therefore, it encourages researchers to explore this issue more deeply.

\section{Methodology}

Using observation methods. Observation is also an alternative in collecting information or collecting data other than questionnaires and interviews (Karim \& Nadzalan, 2017; Karim et al., 2018; Karim, Ghafar, \& Nadzalan, 2018). Through observation, researchers are able to observe a subject behavior based on the variables identified (Rahmat et al., 2017; Rahmat, Shahril, Salimin, Ahmad, \& Nadzalan, 2017; Rahmat, Shahril, Salimin, Ahmad, \& Nadzalan, 2018). The role of the researcher is as an observer of behavioral changes, listening, and viewing the behavior of the subject either from far or near. The population of this study was UPSI students representing the university in football. Using this method, researchers or observers should observe their samples within a certain timeframe. Prior to observation, researchers need to make good planning and careful planning. Each observation must 
have a specific purpose, systematically done, focused, and must be recorded neatly and correctly. Notes made must be accurate, valid, and reliable.

\section{Subject}

The population of this study was UPSI students representing the university in football. The selected sample consists of approximately 25 people. The sample consists of players representing the university from the beginning of the student's entry or who have recently been involved in representing the university, but still have a background in playing high-level football.

\section{Instrument}

Through this study, the instruments used are observational. Observation method is a research method used to measure the research variables. Observation is also an alternative in collecting or collecting data other than questionnaires and interviews (Karim \& Nadzalan, 2017; Karim \& Nadzalan, 2017; Karim, Razak, \& Nadzalan, 2018). Through observation, researchers are able to observe a subject's behavior based on the identified variables. The role of the researcher is as an observer of behavioral changes, listening, and viewing the behavior of the subject either from far or near.

\section{Procedure}

Using this method, researchers or observers should observe their samples within a certain timeframe. Prior to observation, researchers need to make good planning and careful planning. Each observation must have a specific purpose, systematically done, focused, and must be recorded neatly and correctly. Notes made must be accurate, valid, and reliable. The respondents of the study may not be aware of the presence of the observer and thus will exhibit genuine and unproductive behavior. The data obtained are more pure and this will contribute to the accuracy of the collected information. Data collection procedures are taken at every exercise time to see the existence of familiar relationships between mentors and mentee.

\section{Results}

The results were obtained based on observations conducted by the researchers without the realization of the respondents namely Universiti Pendidikan Sultan Idris (UPSI) football athlete. A total of 25 subjects or respondents involved including 2 trainers. As a result of the observation done by the researcher it helps to answer the research questions. This is because the selected subject or respondent has provided good cooperation with each other.

Coaching and mentoring use the same skills and approaches. Coaching based on short-term tasks, while mentoring relationships and long-term tasks. Mentors are usually more experienced than mentee. The focus is on career and personal development. Agenda is created by mentee, with mentors providing support and guidance to prepare them for future roles. Mentoring also completes more relevant develop mentee professionalism. This mentoring system also has a positive impact on the field of sports especially UPSI football teams. The feedback given by coaches and players gives them the opportunity to mentor and mentee learn something. It has also made the relationship between coach and player better. Coach is a leader who can influence and train his athletes to win a victory (Collins, Gould, Lauer, \& Chung, 2009; Thomas, Thomas, \& Firestone, 2015). Building 
relationships and understanding is in the midst of building a good working relationship between mentor and mentee. Relevant knowledge, understanding and skills will definitely help mentors and ments, but they also need to demonstrate a clear commitment to the process through behavior that reflects good interests and values.

The main goal of the coach is to form a successful team and always maintain excellent performance throughout the competition season (Kogler Hill, Hilton Bahniuk, Dobos, \& Rouner, 1989). For example, the UPSI football team performed quite well in the MASUM and IPT league last season. The UPSI football team also managed to put in the top five in the league. This is because, there is a mentoring system among players and coaches with a positive impact and thus strengthening the relationship between the coach and the player. From an observation point made after a training session, players and coaches discuss about the shortcomings that arise in the team and also try to resolve together. Relationships only exist when mentors and mentee know each other in other words as a peer, which each leads to its own and valuable contributions. The agenda was formed jointly and coordinated in response to both the mentor and mentee's interests and desires. This form of relationship is best suited for more experienced mentee and as mentor relationships become steady.

In terms of athlete development towards the mentoring program, the mentoring program will increase individuals or groups to achieve optimum level of commitment. The ability or potential of a person is more visible and applicable in any situation. Mentoring will usually be done professionally or unprofessionally and formally or informally. It will also increase the tendency of an individual to identify problems or constraints that exist at the workplace and will result in continuous improvement of quality. Equal ideas, features and interests shared will form relationships on the basis of common ground. Finding this equation will involve sharing and communication. Once the partnership has taken place and the equation has been found, a connection will be made. Furthermore, building good relationships through communication is not just a word used. It involves body language, gestures and eye contact. Cooperation is very important to contribute to the building of relationships between mentors and mentees, so mentors and mentees must develop a shared approach to the structure, outcome and approach to the relationship.

Mentoring can apply what's learned instantly in real situations by directly linking the tasks given in learning to actual activities. Individuals also have the opportunity to use time and resources allocated more efficiently. In the UPSI football team we can see that the player or athlete's development in terms of psychology, experience and wisdom set the strategy for each match that will be contested with the coach who is the mentor. This mentoring program helps many coaches and players share the problems faced by each other. For example, in the last match in the IPT League, the UPSI team opposed the UITM team but the match sided to the UITM team with a 1-0 win. In the MASUM match, the UPSI team made improvements in tactically and won the game with a 2-1 win against UITM.

\section{Discussion}

Sports coaches are individuals who act as trainers, instructors, mentors and perform sportsrelated tasks. In addition to sports coaching, it is a well-organized process to help an individual or group of athletes learn skills and achieve their goals. From the mentoring program conducted in 
sports organizations, it helps the coach to be strong enough to approach the athlete easily and at the same time give athletic guidance accordingly to improve their performance. According to (Chelladurai, 1980), the higher the level of compatibility between actual behavior and the desired behavior of athletes, the increased performance of athletes and their satisfaction towards organizations and leaders. This study can help trainers and athletes find that there is a positive and strong relationship between technical skills, competition strategies and athlete satisfaction. In this context, a positive and strong relationship between coach behavior as a mentor for physical training and co-planning, setting goals with athlete satisfaction. However, positive and simple relationships exist between mental preparation and athlete satisfaction. In this mentoring program, effective coaches successfully affect the athlete's mood and attitudes towards the burden of duties and responsibilities.

This mentoring program has a positive impact on sports as mentoring can provide mentee with the necessary skills, confidence and self-esteem (Gilley, Dixon, \& Gilley, 2008). For example, through interactions with experienced mentors, a mentee can acquire skills such as mentor, team building, communication, problem solving, which can increase job satisfaction and increase productivity. Mentoring activities such as role models, counseling and friendships can also help the mentee to develop a professional identity and competence within the organization (Kram \& Isabella, 1985). It is also associated with six transformational behaviors - Individual consideration, where leaders show their respect for followers and concerns about their personal feelings and needs. Inspirational motivation, where leaders develop, clarify, and inspire others with their insights into the future. Intellectual stimulation, where leaders challenge followers to review their assumptions about their work, and think again how they can be implemented. Acceptance fostering group goals (where fostering acceptance of group goals), where leaders encourage collaboration among followers and get them towork together towards the same goal. High performance expectations, where leaders express hope for excellence, quality, or high performance on the part of the followers. Suitable role modeling, where leaders are examples of emulating followers who are in harmony with the values the leaders are doing and transaction behavior, contigent reward, in which the leader gives a positive reinforcement in return for behavior Successful behavior and achievement. In this discussion section, it will lead to questions about the effectiveness of the mentoring program on football. According to (Festinger, Schachter, \& Back, 1950) the classic definition of integrity is the overall strength with the members' behavior to play together in the current group on the (Festinger et al., 1950).

Interaction process between coach and athlete is a very important component to improve the performance and satisfaction of an athlete. According to Mallett and Dickens (2009), coaches play a very important role in producing athletes with the skills and knowledge needed to improve the performance of athletes in their sport. Coaches also have enormous influence in creating fun and satisfaction as well as continuous participation of athletes. From the observations done, the coach who mentor the athlete not only share the opinions with each other but the coach is also a good friend if outside training sessions. In addition, this study also looks at the impact on their training if the mentoring program exists. This mentoring program demonstrates the attitude or style of the leadership of a democratic trainer. This finding is further reinforced by Frontiera (2006) which states that knowing the dimensions of leadership style favored by athletes helps coaches to plan and manage training programs with greater confidence, motivation and at the same time the athlete 
enjoys during the training program. The impact of the coach's actions indirectly increases the satisfaction of athletes. The findings are supported by (Chelladurai, 1984) which state the leadership style of trainers for training and instruction dimensions satisfaction and achievement of athletes.

However, the findings of this study differ from Schliesman (1987) which found that democratic dimensions and dimensions of social support were the key predictors of coaching leadership styles to athlete satisfaction. For the UPSI football team, there is no exception of training sessions if in the afternoon they are involved with the lecture. This is because after discussions with coaches and UPSI sports centers they give permission to conduct training sessions during the night. So, from mutual agreement, training sessions can be carried out without any constraints. This shows that this mentoring program helps the UPSI football team to practice without any obstacles. To ensure the quality and training of this mentor, as a skilled coach will use a combination of techniques including listening, questioning, giving feedback and perhaps observing. The whole experience of coaching should be a positive thing even though there are times when the coach should prepare a mentee that is a UPSI football player to challenge because recognizing the need to change and setting the need to address this will make the mentee really commit, build and move forward. The results of the mentoring program are for the mentee. Investment returns are high when mentee is able to implement actions to achieve agreed goals using all the potential in themselves and themselves who choose and decide. Being a coach must help mentee UPSI football players use the potential in themselves to solve their own problems instead of the coach solving the problem of athletes.

From observations conducted by researchers, the mentoring that occurs in the UPSI football team can be seen through the incomparable nature and willingness to sacrifice to achieve the goals set. Their UPSI football athletes do not give up on daily training sessions to maintain their desired game momentum. They are also willing to spend their holidays returning to UPSI for training before the start of the season. This mentoring program can also cultivate pure values in athletes with high self-discipline, always practice clean games, have good track record throughout sports engagement, have a high morale spirit, demonstrate high commitment to the team and intelligently control emotions while in court. High self-discipline can help an athlete to be at the top of brilliance. A disciplined athlete will easily get support from the community. Disciplined athletes know their roles and responsibilities, obeying the heads and coaches' instructions, according to well-defined training schedules and respecting other teammates. Disciplined athletes are also able to control emotions to avoid unwanted things happening during the game. Failure to control emotions during play will have a negative impact on yourself or your team. As athletes must understand the laws, strategies, tactics and skills in a game. The game's ethics and rules need to be clearly understood. A clear understanding of game ethics can prevent players from making mistakes while playing.

Collaboration is also important in a game. Athletes will enjoy the fun of playing and thus the victory will be celebrated together while defeat will not be held accountable to the individual in the team. In addition, loyalty to the team is necessary to ensure close collaboration among athletes. Aggressive action such as bribery in previously played teams stems from unfaithful behavior to the team and the attitude of some individuals who are dishonest and trustworthy. In addition, the determination and high spirits are one of the success factors of an athlete. An athlete who wishes to progress must want to improve his performance and be willing to accept criticism from the openminded community. Athletes who have a good personality will be highly regarded by the community 
and can be an example to the community. The findings showed that the mentoring program practiced by the Sultan Idris University's football team had a positive impact and improved the performance of athletes with good relationships between coaches and teams. This finding further demonstrates a positive outcome for the development of athletes as athletes themselves feel satisfied with the leadership given by their coaches. It is also supported by Mohd Sofian, (2001) has defined the team's integrity to refer to the tendency of members in a team or united organization to achieve a goal.

\section{Conclusion}

Overall, the mentoring program practiced by the Sultan Idris University football team involved with the Malaysian University Sports Council (MASUM) can help trainers and athletes find that there is a positive and strong relationship between technical skills, competitive strategy and athlete satisfaction. In this context, a positive and strong relationship between coach behavior as a mentor for physical training and co-planning, setting goals with athlete satisfaction. This mentoring program can also cultivate pure values in athletes with high self-discipline, always practice clean games, have good track record throughout sports engagement, have a high morale spirit, demonstrate high commitment to the team and intelligently control emotions while in court.

\section{Acknowledgement}

This study is funded by Universiti Pendidikan Sultan Idris.

\section{References}

Bahniuk, M. H., \& Hill, S. K. (1998). Promoting career success through mentoring. Review of business, 19(3), 4-8.

Chelladurai, P. (1980). A contingency model of leadership in athletics.

Chelladurai, P. (1984). Discrepancy between preferences and perceptions of leadership behavior and satisfaction of athletes in varying sports. Journal of Sport Psychology, 6(1), 27-41.

Collins, K., Gould, D., Lauer, L., \& Chung, Y. (2009). Coaching Life Skills through Football. International Journal of Coaching Science, 3(1), 29-54.

Festinger, L., Schachter, S., \& Back, K. (1950). Social pressures in informal groups; a study of human factors in housing.

Friday, E., \& Friday, S. S. (2002). Formal mentoring: is there a strategic fit? Management Decision, 40(2), 152-157.

Frontiera, J. (2006). The relationship between leadership, efficacy belief, and performance among boys' high school basketball players.

Gilley, A., Dixon, P., \& Gilley, J. W. (2008). Characteristics of leadership effectiveness: Implementing change and driving innovation in organizations. Human Resource Development Quarterly, 19(2), 153-169.

Goldstein, I. L., \& Ford, J. (2002). Training in organizations: Needs assessment, development, and evaluation Wadsworth. Belmont, CA.

Hawkey, K. (1997). Roles, responsibilities, and relationships in mentoring: A literature review and agenda for research. Journal of Teacher Education, 48(5), 325-335. 
Hunt, D. M., \& Michael, C. (1983). Mentorship: A career training and development tool. Academy of Management Review, 8(3), 475-485.

Irving, S. E., Moore, D. W., \& Hamilton, R. J. (2003). Mentoring for high ability high school students. Education+ Training, 45(2), 100-109.

Karim, Z., \& Nadzalan, A. M. (2017). The development of coaching knowledge among Malaysian accredited football coaches. International Journal of Academic Research in Progressive Education and Development, 6(4), 113-127.

Karim, Z. A., Arif, M. Z., Rahmat, A., Azmi, S. H., Tan, K., \& Nadzalan, A. M. (2018). Youth participation patterns in physical activity and sports: the study in urban poverty area in Kuala Lumpur. Journal of Fundamental and Applied Science, 10(5S), 1149-1160.

Karim, Z. A., Ghafar, N. A. A., \& Nadzalan, A. M. (2018). The leadership style among football coaches leadership style among teachers in Hulu Langat district: The implications on National Football Development Program (NFDP) in Malaysia. International Journal of Academic Research in Business and Social Sciences, 8(3), 551-558.

Karim, Z. A., \& Nadzalan, A. M. (2017). The development of coaching knowledge among Malaysian accredited football coaches. International Journal of Academic Research in Progressive Education and Development, 6(4), 113-127.

Karim, Z. A., \& Nadzalan, A. M. (2017). Malaysia football coaches: Development characteristics. International Journal of Academic Research in Business and Social Sciences, 7(9), 305-312.

Karim, Z. A., Razak, A. N. A., \& Nadzalan, A. M. (2018). Designing model of career path development for National Football Development Program (NFDP): directions, issues, challenges and sources of knowledge that influence and develop coaching expertise level. International Journal of Academic Research in Business and Social Sciences, 8(3), 542-550.

Kogler Hill, S. E., Hilton Bahniuk, M., Dobos, J., \& Rouner, D. (1989). Mentoring and other communication support in the academic setting. Group \& Organization Studies, 14(3), 355368.

Kram, K. E., \& Isabella, L. A. (1985). Mentoring alternatives: The role of peer relationships in career development. Academy of Management Journal, 28(1), 110-132.

MacGregor, L. (2000). Mentoring: the Australian experience. Career Development International, 5(4/5), 244-249.

Mallett, C. J., \& Dickens, S. (2009). Authenticity in formal coach education. International Journal of Coaching Science, 3(2), 79-90.

Oliver, C., \& Aggleton, P. (2002). Mentoring for professional development in health promotion: $A$ review of issues raised by recent research. Health Education, 102(1), 30-38.

Rahmat, A., Shahril, M., Salimin, N., Ahmad, M., Elumalai, G., Johan, R., \& Nadzalan, A. M. (2017). Cognitive domain achievement level among Reserve Officers Training Team (PALAPES). International Journal of Academic Research in Business and Social Sciences, 7(11), 198-203.

Rahmat, A., Shahril, M. I., Salimin, N., Ahmad, M. A. R., \& Nadzalan, A. M. (2017). The assessment of psychomotor domain among Reserve Officers Training Team (PALAPES). Journal of Fundamental and Applied Science, 9(6S), 1389-1397. 
Rahmat, A., Shahril, M. I., Salimin, N., Ahmad, M. A. R., \& Nadzalan, A. M. (2018). The assessment of affective domain among PALAPES in UPSI. International Journal of Academic Research in Business and Social Sciences, 8(1), 293-299.

Schliesman, E. S. (1987). Relationship between the congruence of preferred and actual leader behavior and subordinate satisfaction with leadership. Journal of Sport Behavior, 10(3), 157.

Stewart, J., \& Knowles, V. (2003). Mentoring in undergraduate business management programmes. Journal of European Industrial Training, 27(2/3/4), 147-159.

Thomas, T., Thomas, J., \& Firestone, H. (2015). Mentoring, coaching, and counseling: Toward a common understanding. Military Review, 95(4), 50-57.

Wright, R. G., \& Werther Jr, W. B. (1991). Mentors at work. Journal of Management Development, $10(3), 25-32$. 